\title{
Mass appearance of the Ponto-Caspian invader Pontogammarus robustoides in the River Tisza catchment: bypass in the southern invasion corridor?
}

\author{
Zoltán Csabai ${ }^{1, *}$, Péter Borza ${ }^{2}$, Tomasz Rewicz ${ }^{3,4}$, Bálint Pernecker ${ }^{1}$, Balázs J. Berta ${ }^{1}$ \\ and Arnold Móra ${ }^{1}$ \\ ${ }^{1}$ University of Pécs, Faculty of Sciences, Department of Hydrobiology, Ifjúság útja 6, 7624 Pécs, Hungary \\ ${ }^{2}$ MTA Centre for Ecological Research, Danube Research Institute, Karolina út 29, 1113 Budapest, Hungary \\ ${ }^{3}$ University of Lodz, Department of Invertebrate Zoology \& Hydrobiology, Banacha 12/16, 90-237 Lodz, Poland \\ ${ }^{4}$ University of Guelph, Centre for Biodiversity Genomics, 50 Stone Road East, Guelph, ON, N1G2W1, Canada
}

Received: 25 November 2019 / Accepted: 14 January 2020

\begin{abstract}
The river Danube is the backbone of the 'southern invasion corridor', one of the most important passages for the spread of Ponto-Caspian invaders in Europe. However, not all of these species used the passive or active upstream movement in the main channel to reach the upper sections and tributaries, some found detours. Mass occurrences of the Ponto-Caspian peracarid, Pontogammarus robustoides (Sars, 1894) were recorded at 17 sites along the entire Hungarian section of the River Maros, for the first time in the River Tisza catchment and also in Hungary. Those populations are found ca. $707 \mathrm{~km}$ upstream from the closest known and confirmed locality in the lower Danube section. We confirmed their identity by DNA barcoding and showed that all individuals fit in with the lower Danube population, thus identifying the source of this introduction. The most likely vector allowing the jump dispersal of the species is fish stocking in the Romanian section of the River Maros, which - combined with downstream drift to the Serbian Danube section and the relatively busy ship traffic between Belgrade and Vienna - might provide the opportunity to bypass the dispersal barrier represented by the unregulated Middle Danube and open the way towards Western Europe.
\end{abstract}

Keywords: Amphipoda / DNA barcoding / alien species / River Maros / Hungary

Résumé - Apparition massive de l'envahisseur Pontogammarus robustoides dans le bassin versant de la Tisza : contournement du couloir d'invasion sud ? Le Danube est l'épine dorsale du "corridor d'invasion sud", l'un des passages les plus importants pour la propagation des envahisseurs ponto-caspiens en Europe. Cependant, toutes ces espèces n'ont pas fait un déplacement passif ou actif vers l'amont dans le chenal principal pour atteindre les sections supérieures et les affluents, certaines ont trouvé des détours. Des occurrences massives du péracaride ponto-caspien Pontogammarus robustoides (Sars, 1894) ont été enregistrées sur 17 sites le long de toute la section hongroise de la rivière Maros, pour la première fois dans le bassin versant de la rivière Tisza et également en Hongrie. Ces populations se trouvent à environ $707 \mathrm{~km}$ en amont de la localité connue et confirmée la plus proche dans le bassin versant du Danube inférieur. Nous avons confirmé leur identité par un barcoding $\mathrm{ADN}$ et montré que tous les individus correspondent à la population du Danube inférieur, ce qui permet d'identifier la source de cette introduction. Le vecteur le plus probable permettant la dispersion par saut de l'espèce est le déversement de poissons dans la section roumaine du fleuve Maros, qui - combiné à la dérive aval vers la section serbe du Danube et au trafic maritime relativement intense entre Belgrade et Vienne - pourrait permettre de contourner la barrière de dispersion que représente le Danube moyen non régulé et d'ouvrir la voie vers l'Europe occidentale.

Mots-clés : Amphipode / DNA barcoding / espèces exotiques / Rivière Maros / Hongrie

\footnotetext{
*Corresponding author: csabai@gamma.ttk.pte.hu
} 


\section{Introduction}

The River Danube is one of the most important corridors promoting the spread of Ponto-Caspian species towards Central and Western Europe ('southern invasion corridor'; Bij de Vaate et al., 2002). The majority of the invaders are lithophilous peracarid crustaceans which followed a similar pattern during their range expansion; all species reached the upper parts of the river by jump dispersal and colonized the intermediate section by downstream drift (Borza et al., 2015, 2017). However, in the case of the latest colonist - the psammo-pelophilous Paramysis lacustris (Czerniavski, 1882) - the establishment in the Middle Danube (Borza et al., 2019) was preceded by the appearance in the River Tisza (Borza and Boda 2013).

Pontogammarus robustoides (Sars, 1894) is a large (body length up to $21 \mathrm{~mm}$ ) invasive amphipod of Ponto-Caspian origin. It occurs natively in the Caspian Sea and the lower courses and estuaries of large rivers: Volga, Terek, Kura, Kuban, Don, Dnieper, Dniester, Danube, and Prut, as well as in brackish and freshwater lakes in the basin of the Black Sea (Dedju, 1980; Jazdzewski, 1980; Özbek, 2011; Rewicz et al., 2016). The species was successfully introduced to dam lakes on the Dnieper, Nemunas, and Daugava rivers in the early 1960s (Mordukhai-Boltovskoi, 1964; Arbačiauskas, 2002). From this initial area, the species was able to spread probably along the Baltic coast in a south-western and northern direction. It reached the Gulf of Finland and the Neva river (Panov and Berezina, 2002) and continued eastward expansion to Lake Ladoga (Kurashov and Barbashova, 2008). Spreading south continued through Curonian lagoon (Arbačiauskas, 2005), Vistula Lagoon, Masurian Lakes, the Oder estuary in western Poland, and in 1994, the Peene river in Germany (summarized by Jazdzewska and Jazdzewski, 2008). Soon after that, the species was found in several watercourses in Mecklenburg-Vorpommern (1996-1997, 2014-2015) and in 1998 also in the Mittellandkanal (Zettler, 1998; Messner and Zettler, 2016). The last notice reports occurrence of this species in the Netherlands (Moedt and van Haaren, 2018).

In the River Danube it showed little propensity for range expansion so far. A single record of the species in the Iron Gate 1 reservoir (river km 1072-943) was published (PopescuMarinescu et al., 2001); however, it has not been confirmed since then. During the 3rd Joint Danube Survey (2013), the most upstream occurrence of the species was at river $\mathrm{km} 686$, at Kozloduy, more than $250 \mathrm{~km}$ downstream from the Iron Gate 1 (Borza et al., 2015).

In this study, we provide a first report on the occurrence of $P$. robustoides in the River Tisza catchment in Hungary, Central Europe, as well as the genetic identification based on the portion of cytochrome oxidase (COI) gene used as a DNA barcode.

\section{Materials and methods}

\subsection{Field sampling}

Samples were taken at about every two kilometers throughout the entire Hungarian section of the River Maros

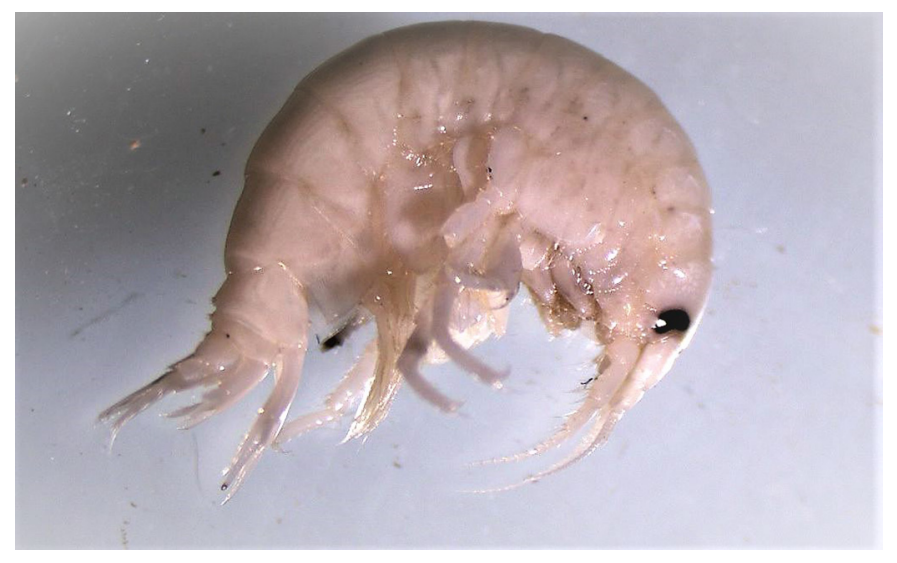

Fig. 1. Specimen of Pontogammarus robustoides collected in Hungary (River Maros, location \#12 at Makó, 27 March 2019, leg. A. Móra, photo credits: Grzegorz Tończyk).

for a complete study of the macroinvertebrate assemblages. In spring (27-28 March 2019), altogether 22 sampling points had been sampled by using dredge nets (triangular framed, braced and scraper toothed, chain and rope towed sampling device with a $40 \mathrm{~cm}$ long, $0.5 \mathrm{~mm}$ mesh-sized net). The dredge sampler was thrown into the water and, after its orientation due to the water flow, was towed approximately one-meter-long in flow direction. It bit and collected the upper surface of the sediment providing a sample which was moved into covered buckets and were separated using trays on the shore of the river. One site (locality \#12 at Makó) during the spring sampling campaign and 19 sites in summer (17-18 July and 15 August 2019) were also sampled with standard hand-nets (pentagonal framed, 0.5 and $1 \mathrm{~mm}$ mesh-sized nets with $1.5 \mathrm{~m}$ long handles). Dredging and most of the hand-net samplings were implemented from a small motorboat; in cases of some hand-net samplings the water was approached from the shore by feet and only the accessible littoral zone was sampled. Hand-net samples were taken from coastal vegetation hanging into the water, floating and anchored woody debris, and garbage islands, sometimes from stony embankments. Collected individuals were preserved in $96 \%$ ethanol directly in the field. In the laboratory, the material was identified to the species level under a Nikon SMZ-800 stereomicroscope, based on available literature (i.e. Mordukhai-Boltovskoi et al., 1969; Eggers and Martens, 2001) and stored in the permanent collection of the Department of Hydrobiology, University of Pécs, Hungary. Individuals used for molecular identification are stored in the permanent collection of the Department of Invertebrate Zoology and Hydrobiology, University of Lodz, Poland.

\subsection{Genetic analysis}

The total DNA of three individuals (locality \#12 River Maros at Makó, hand-net samples in spring) identified as $P$. robustoides (Fig. 1) was extracted from their fifth pereiopod, with the Chelex procedure (Casquet et al., 2012). The COI fragments were amplified using the LCO1490 JJ/HCO2198 JJ primer pair (Astrin and Stüben, 2008). We used reaction 
Z. Csabai et al.: Knowl. Manag. Aquat. Ecosyst. 2020, 421, 9

Table 1. Material of Pontogammarus robustoides and Pontogammarus maeoticus used in our study.

\begin{tabular}{|c|c|c|c|c|c|c|c|}
\hline No. & GenBank acc. & BOLD process ID & Locality & Latitude, $\mathrm{N}$ & Longitude, E & $\mathrm{N}$ & Reference \\
\hline & $\begin{array}{l}\text { Pontogammarus robustoides } \\
\text { (Sars, 1894) }\end{array}$ & & & & & & \\
\hline 1. & MN322612 - MN322614 & $\begin{array}{l}\text { PROB1572-19 - } \\
\text { PROB1574-19 }\end{array}$ & Hungary, River Maros & 46.196 & 20.471 & 3 & This study \\
\hline 2. & MN322615, MN322616 & $\begin{array}{l}\text { PROB138-18, } \\
\text { PROB141-18 }\end{array}$ & $\begin{array}{l}\text { Ukraine, River Dnieper } \\
\text { in Cherson }\end{array}$ & 46.675 & 32.720 & 2 & This study \\
\hline 3. & MN322611 & PROB246-18 & Ukraine, Sasyk lagoon & 45.540 & 29.655 & 1 & This study \\
\hline 4. & KF478538 & GBCMA12771-16 & $\begin{array}{l}\text { Ukraine, Harkiv, Biškin, } \\
\text { r. Severski Donec }\end{array}$ & $49.980^{*}$ & $36.881^{*}$ & 1 & Hou et al., 2013 \\
\hline 5. & NA & $\begin{array}{l}\text { CCNUN401-07, } \\
\text { CCNUN406-07 }\end{array}$ & $\begin{array}{l}\text { Kazakhstan, Caspian } \\
\text { Sea }\end{array}$ & 41.617 & 50.352 & 2 & BOLD public \\
\hline 6. & AY529045 & GBCMA0100-06 & Russia, River Pregola & $54.706^{*}$ & $20.501^{*}$ & 1 & Cristescu and Hebert 2005 \\
\hline 7. & AY189507, AY189505 & $\begin{array}{l}\text { GBCMA0065-06, } \\
\text { GBCMA0067-06 }\end{array}$ & $\begin{array}{l}\text { Romania, Sfântu } \\
\text { Gheorghe, Danube }\end{array}$ & $44.894^{*}$ & $29.593^{*}$ & 2 & Cristescu et al., 2003 \\
\hline 8. & AY189509 & GBCMA0069-06 & Russia, River Volga & $48.648^{*}$ & $44.456^{*}$ & 1 & Cristescu et al., 2003 \\
\hline \multirow[t]{2}{*}{10.} & AY529043, AY189506 & $\begin{array}{l}\text { GBCMA0098-06, } \\
\text { GBCMA0066-06 }\end{array}$ & Ukraine, Kahul lake & $45.367^{*}$ & $28.331^{*}$ & 2 & $\begin{array}{l}\text { Cristescu et al., 2003, } \\
\text { Cristescu and Hebert } 2005\end{array}$ \\
\hline & $\begin{array}{l}\text { Pontogammarus } \\
\text { maeoticus (Sovinskij, 1894) } \\
\text { MN322617 }\end{array}$ & PROB458-18 & $\begin{array}{l}\text { Ukraine, Dnieprovski } \\
\text { Liman }\end{array}$ & 46.617 & 32.074 & 1 & This study \\
\hline
\end{tabular}

${ }^{*}$ Approximate coordinates.

conditions following Hou et al. (2007). PCR products $(5 \mu \mathrm{l})$ were cleaned up by Exonuclease I ( $2 \mathrm{U}$, Thermo Scientific) and alkaline phosphatase FastAP (1 U, Thermo Scientific) treatment, according to the manufacturer's guidelines and sent for sequencing to the Macrogen Inc., Korea. The identity of the obtained sequences was verified with BLAST (Altschul et al., 1990). The obtained sequences were edited, aligned and trimmed to 608 bp using Geneious 10.2 (Kearse et al., 2012) and deposited in GenBank under accession numbers (MN322611 - MN322617). Simultaneously, the DNA sequences were deposited in the online database of the Barcode of Life Data Systems (BOLD) (Ratnasingham and Hebert, 2007), in order to obtain the Barcode Index Numbers (BIN) that group DNA sequences based on the genetic distance, as tentative equivalents of species (Ratnasingham and Hebert, 2013). Obtaining BINs for sequences deposited in BOLD provides an additional verification of species identification. Haplotypes were identified using the DnaSP 5.10.01 software (Librado and Rozas, 2009). Additional COI sequences of $P$. robustoides (12 individuals) as well as the outgroup sequence (one individual) of the Pontogammarus maeoticus (Sovinskij, 1894) were acquired from open databases (GenBank and BOLD) as well as from own data (see Tab. 1 for details). The phylogenetic tree was constructed using the sequence data from dataset in MEGA 6 (Tamura et al., 2013) with the neighbor-joining method (NJ) (Saitou and Nei, 1987) based on the p-distance (Nei and Kumar, 2000) with a bootstrap test performed on 1000 replicates. The $\mathrm{K} 2 \mathrm{P}$ pairwise genetic distances were calculated in MEGA6 software (Tamura et al., 2013). Relevant voucher information is accessible through the public data set "PROBHUN" (DOI: http://dx.doi.org/10.5883/DS-PROBHUN) in the Barcode of Life Data Systems (BOLD; http://v4.boldsystems.org).

\section{Results}

We recorded the occurrence of $P$. robustoides at 17 sampling sites along the entire section of the River Maros (Fig. 2), for the first time in Hungary. The species had not been found in sediment samples taken by using dredging method. It was exclusively collected with hand-net samplings from the shore vegetation hanging into the water, from anchored and/or floating woody debris and garbage, and from stone embankments (Fig. 3). Although our samples cannot be considered either quantitative or semiquantitative samples, but a very high numbers of individuals were collected at the sites: altogether 402 specimens were preserved, the number of individuals preserved per site varied between 1 and 87 . Based on this, and on the fact that the species were found at all but two net-sampled sites, the occurrence of the species throughout the River Maros can be clearly identified as mass occurrence. The species seems to be the dominant species in the amphipod community of the Hungarian section of the river, besides this only Dikerogammarus villosus (Sovinski, 1894) was found but in lower density, at 6 sites, exclusively in the lower section of the river with 1 up to 10 individuals per sample.

The DNA barcoding confirmed that all the obtained sequences belonged to $P$. robustoides. We have identified two haplotypes differing in one base pair from Hungary. The pairwise K2P distance did not exceed $3.62 \%$ for all sequences of $P$. robustoides gathered in our dataset. The sequences from Hungary were grouped in one BIN (BOLD: AAB7665) which is the only one known for available data of $P$. robustoides, so far. All sequences from Hungary form one well supported clade with sequences from specimens found in the Danube delta (Fig. 4). One haplotype identified in this study occurring 


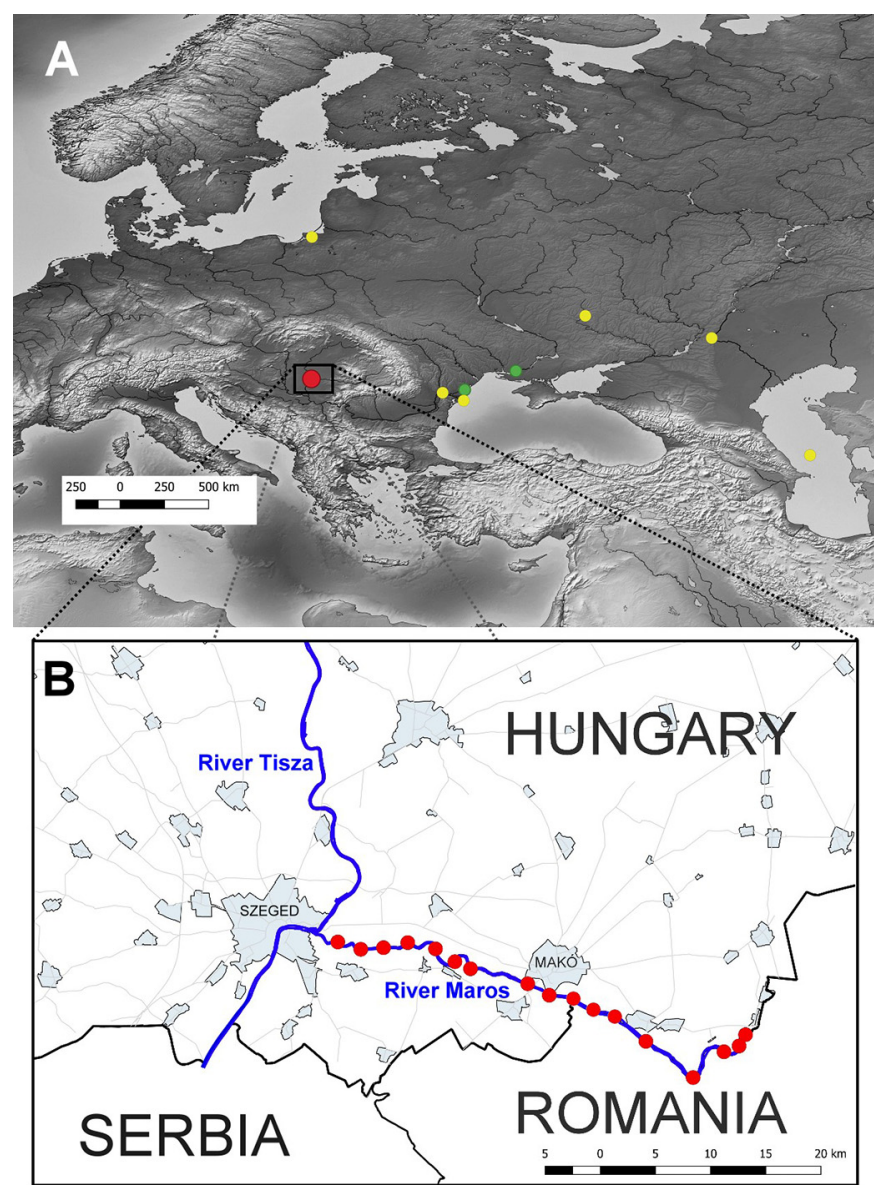

Fig. 2. (A) Samples of Pontogammarus robustoides used in this study. Yellow dots: sequences gathered from literature data, red dot: location of $P$. robustoides in Hungary, green dots: sequences added to dataset from own collection. (B) Zoom map of SE Hungary with the river system and the localities (red dots) where P. robustoides was collected in 2019. Numbering of the sampling sites started with \#1 at the entry of the river to Hungary and ended with \#22 at the mouth to River Tisza. Sites \#2, 5, 7, 14, and 22 are not indicated on the map because P. robustoides had not been recorded at these five sites.

in Hungary was identical with one already recorded from Danube delta by Cristescu et al. (2004), second haplotype was new; however, it fits inside the clade. It is clearly divided from specimens from Dnieper and Caspian population (Volga river) (Fig. 4).

\section{Discussion}

Our results represent the first record of $P$. robustoides from the territory of Hungary, extending its distributional range in the Danube catchment by 707 river km (from most upstream JDS3 record, Borza et al., 2015). The molecular results confirmed the identity of the invader and based on available molecular data we were able to establish a connection to the native populations of the Danube catchment. However, a more accurate identification of the possible source population and

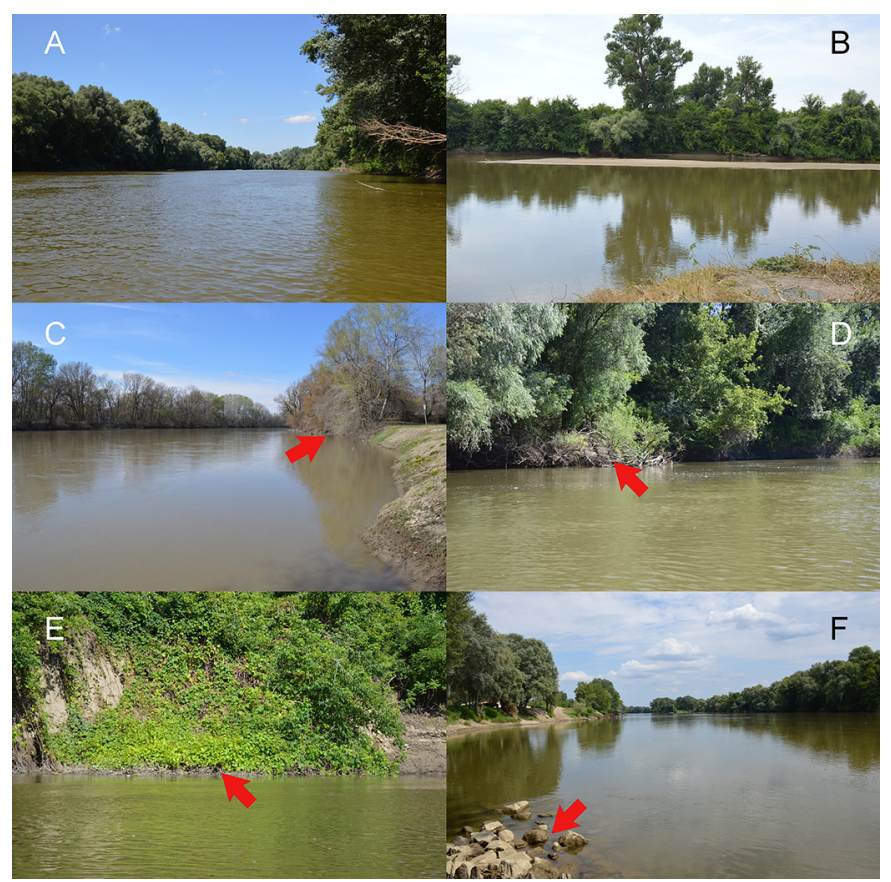

Fig. 3. Characteristic habitats and sampling sites along the Hungarian section of the River Maros. (A) General appearance in summer. (B) Characteristic view in summer with a typical sand reef in the middle of the river. (C)-(E) Typical habitats for Pontogammarus robustoides indicated with red arrows. (C) Riparian woody vegetation hanging into the water, location \#12 at Makó in spring, this site provided the three specimens barcoded for this study. (D) Anchored woody debris and garbage, location \#21 at Szeged in summer. (E) Littoral shrubs hanging into the water, location \#18 at Maroslele in summer. (F) Stony embankment, location \#08 at Magyarcsanád in summer (photo credits: Arnold Móra).

the type of introduction would require the investigation of more specimens as well as more sampling sites from the native and also from the invaded regions. In this paper, we discuss our preliminary conclusions we could draw based on the currently available information.

Judging by the presence of large overwintering individuals in March 2019 and the high abundance of the species during the summer sampling campaign, it can be assumed that the colonization of the studied river section took place in the previous reproductive period or even earlier. Based on the large distance from the most upstream occurrence of $P$. robustoides known in the catchment and the lack of recent records in the intermediate river sections (Borza et al., 2015), the possibility of a gradual active upstream spread can be excluded with high certainty. Since the River Maros is navigable only until river km 15 by larger ships and until Makó $(25 \mathrm{~km})$ by small ones, the role of shipping in the spread of the species is not likely either. Transport by waterfowl is also unlikely because, according to the only study about it known by us (Rachalewski et al., 2013), it can operate only within several kilometers. In our opinion, the most likely vector allowing the jump dispersal of the species is fish stocking (i.e. unintentional transport in fish tanks; Borza et al., 2011) in the 


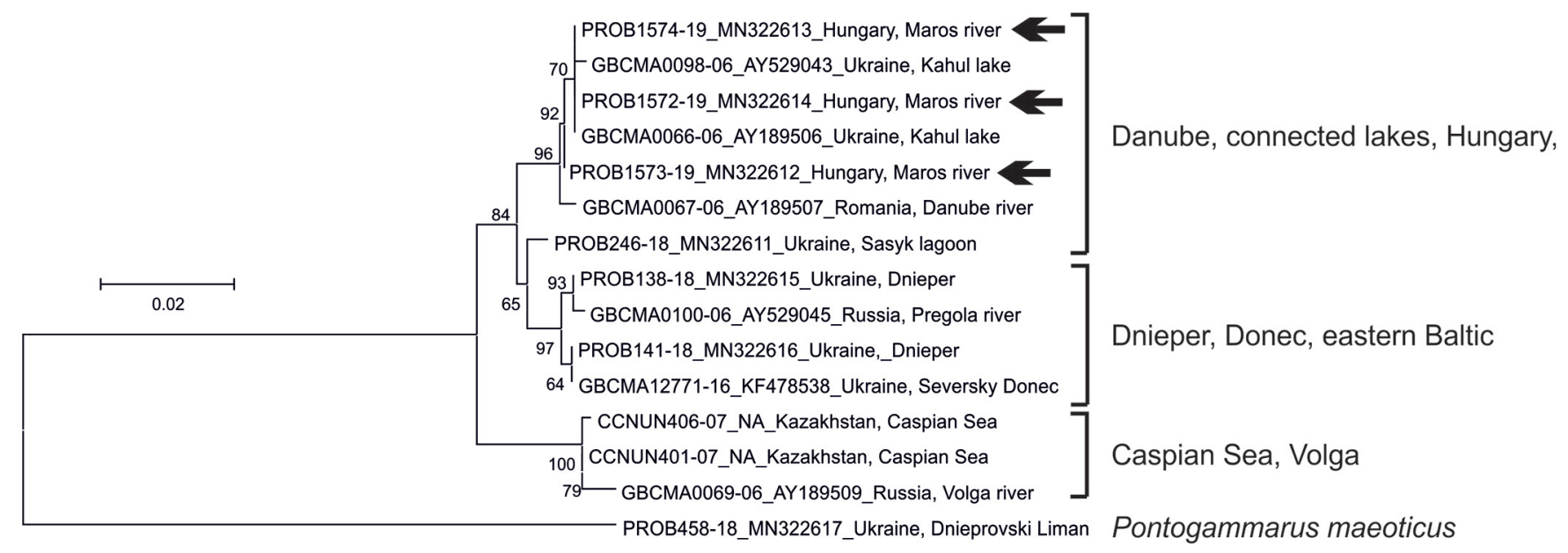

Fig. 4. Neighbor-joining tree based on COI K2P distance for sequences of Pontogammarus robustoides COI from some native and invasive populations (see Fig. 2 and Tab. 1 for details). Black arrows indicate sequences coming from Hungary, obtained in this study. Square brackets indicate the geographic origin of the sequences. Each sequence name consists of three parts separated by lower dash: (1) BOLD Process ID, (2) GenBank accession number, (3) locality.

Romanian section of the River Maros or in other water bodies (e.g. oxbows or fishing ponds) connected to the river.

The autecology of $P$. robustoides as well as its interactions with other species is relatively well studied due to its previous range expansion in the Baltic sea basin. It has a fast reproductive cycle with 3 generations per year in spite of its large body size, and its fecundity is exceptionally high even compared to other invasive Ponto-Caspian gammarids, which might contribute to its invasion success (Bacela and Konopacka, 2005; Grabowski et al., 2007). It can adapt to a broad range of salinity (Dobrzycka-Krahel and Surowiec, 2011) as well as to low oxygen levels (Šidagytè and Arbačiauskas, 2016), which allows it to colonize different types of habitats, including brackish estuaries and lagoons, and hypertrophic lakes. In this regard, the recently colonized River Maros does not represent an extreme environment for the species.

The habitat preference of the species is rather complex. Dedju (1980) characterized this species as phytophilous; however, it clearly shows morphological and behavioral adaptations for living on soft substrates as it can burrow itself into the upper several $\mathrm{cm}$ of the sediment (Poznańska et al., 2013). This ambiguous substrate preference has been observed in the invaded regions where the species mostly inhabits shallow sandy habitats and macrophytes in the offshore zones of reservoirs (Żytkowicz et al., 2008), as well as in the native range (Borza et al., 2017). Experimental studies have shown that the habitat preference observable in nature might evolve in response to the presence of competitors and predators (Jermacz et al., 2015; Kobak et al., 2017).

In our survey, all $P$. robustoides individuals, and practically every other macroinvertebrate individuals (except chironomids from the middle section, three caddisfly larvae and a single mayfly larva) were captured by using standard handnets. Only in the lowest sampling point, where the sediment is more varied due to the back-swelling effect of the River Tisza, the dredging was a more successful method. This is clearly due to the fact that the sediment of the River Maros is almost exclusively consisted of continuously moving sand. The suspended sediment discharge of the river is considerably high. Almost any flood, even the smaller ones, may form the structure of the riverbed like moving the banks and nodes (Kiss et al., 2011). In this continuously changing environment only extreme specialist (some chironomids, e.g. Chernovskiia spp., see Pinder, 1995) can live and survive. Aquatic invertebrates, including amphipods, are using the additional habitats along the shores and/or floating on the water surface, e.g. stones, wood trunks fallen into the riverbed, wooden parts, hanging vegetation, floating debris and garbage. Pontogammarus robustoides individuals were found in almost all types of these habitats. However, the real mass occurrences were most frequently recorded from under the soaked bark of thinner and thicker wood branches and trunks, where individuals could hide. Such observation, and the methodological fact that the regular monitoring activities in Hungary are focused mostly on the sediment samples, may explain how the species' mass invasion in the entire section of the River Maros had not been recorded earlier.

The impact of $P$. robustoides might be primarily related to its trophic interactions. Stable isotope and gut content analyses have shown that the species, similarly to the 'killer shrimp' $D$. villosus, occupies a relatively high trophic position due to its mixed diet of animal prey and plant detritus (BacelaSpychalska and Van der Velde, 2013). The predatory feeding of the species might induce considerable changes in the composition and abundance of the macroinvertebrate assemblage, especially in the upstream sections of the River Maros where other amphipod species of similar dietary properties are absent. Competitive interactions with other Ponto-Caspian gammarids might result in moderate changes in their abundances; however, the species are capable of stable coexistence by spatial niche differentiation. The appearance of $P$. robustoides might also affect food availability for fish; nevertheless, the direction of the effect is not evident. The species itself can serve as diet for fish (somewhat more favorable than $D$. villosus due to its softer exoskeleton (Błońska et al., 2015)); however, its predatory diet might result in an overall decrease in food availability. 


\section{Conclusions}

After P. lacustris, P. robustoides is the second psammopelophilous Ponto-Caspian peracarid expanding its range in the River Danube catchment. Its high abundance in the studied area indicates that the conditions offered by the lowland rivers of the Carpathian basin are favorable for the species, portending its further spread in the region. The colonization of the Serbian part of the River Tisza as well as the Danube section downstream of the confluence with the Tisza is highly probable which might also promote the upstream spread of the species in the Danube, taking the patterns in ship traffic into account. Several passenger ships travel between Belgrade and Vienna which might enable the species to cross the unregulated Middle Danube and reach the impoundments of Austria and Slovakia where its establishment might be easier (protection from currents, soft sediments). Although other vector mechanisms were suggested in the case of P. lacustris, we suppose that the scenario presented here (fish stocking in the Tisza catchment, and shipping between Belgrade and Vienna) might also have been responsible for its spread. We expect that this mechanism might allow $P$. robustoides and potentially additional psammo-pelophilous Ponto-Caspian peracarids to bypass the dispersal barrier represented by the unregulated Middle Danube and open the way for further spread towards Western Europe.

Acknowledgements. Authors would like to thank Júlia Szeles (University of Debrecen) for her assistance in sample sorting during the field work in spring, Tibor Danyik (indep. res.) for contributing to the summer sampling, Éva Tihanyi (University of Pécs) for sorting the samples in the lab and Péter Lovászi and Viktoria Bóta (Körös-Maros National Park Directorate) for their help in arranging the technical details and logistics of the fieldwork. We would like to thank Grzegorz Tończyk for taking a picture of species. ZC, BP, AM were supported by the Higher Education Institutional Excellence Programme of the Ministry of Human Capacities in Hungary, within the framework of the 20765-3/2018/FEKUTSTRAT and TUDFO/ 47138/2019-ITM "Innovation for sustainable and healthy living and environment" thematic programme of the University of Pécs. TR was supported partially from the National Science Centre (Poland), project 2017/01/X/NZ8/01086, by the Scholarship of the Polish National Agency for Academic Exchange (NAWA) at Bekker Programme nb. PPN/BEK/ 2018/1/00162/U/00001 and partially from internal funds of the University of Łódź, BP and BB were supported by the EU-funded project no. EFOP-3.6.1.-16-2016-00004.

\section{References}

Altschul SF, Gish W, Miller W, Myers EW, Lipman DJ. 1990. Basic local alignment search tool. J Mol Biol 215: 403-410.

Arbačiauskas K. 2002. Ponto-Caspian amphipods and mysids in the inland waters of Lithuania: history of introduction, current distribution and relations with native malacostracans. In Leppäkoski E, Gollasch S, Olenin S, eds. Invasive Aquatic Species of Europe - Distribution, Impacts and Management. Dordrecht, The Netherlands: Kluwer Academic Publishers, pp. 104-115.
Arbačiauskas K. 2005. The distribution and local dispersal of PontoCaspian Peracarida in Lithuanian fresh waters with notes on Pontogammarus robustoides population establishment, abundance and impact. Oceanol Hydrobiol St 34: 93-111.

Astrin JJ, Stüben PE. 2008. Phylogeny in cryptic weevils: molecules, morphology and new genera of western Palaearctic Cryptorhynchinae (Coleoptera: Curculionidae). Invertebr Syst 22: 503-522.

Bącela K, Konopacka A. 2005. The life history of Pontogammarus robustoides, an alien amphipod species in Polish waters. J Crustac Biol 25: 190-195.

Bącela-Spychalska K, Van der Velde G. 2013. There is more than one 'killer shrimp': trophic positions and predatory abilities of invasive amphipods of Ponto-Caspian origin. Freshw Biol 58: 730-741.

Bij de Vaate A, Jażdżewski K, Ketelaars HAM, Gollasch S, Van der Velde G. 2002. Geographical patterns in range extension of PontoCaspian macroinvertebrate species in Europe. Can J Fish Aquat Sci 59: 1159-1174.

Błońska D, Grabowska J, Kobak J, Jermacz Ł, Bącela-Spychalska K. 2015. Feeding preferences of an invasive Ponto-Caspian goby for native and non-native gammarid prey. Freshw Biol 60: 2187-2195.

Borza P, Boda P. 2013. Range expansion of Ponto-Caspian mysids (Mysida, Mysidae) in the River Tisza: first record of Paramysis lacustris (Czerniavsky, 1882) for Hungary. Crustaceana 86: 1316-1327.

Borza P, Czirok A, Deák C, et al. 2011. Invasive mysids (Crustacea: Malacostraca: Mysida) in Hungary: distributions and dispersal mechanisms. North-West J Zool 7: 222-228.

Borza P, Csányi B, Huber T, et al. 2015. Longitudinal distributional patterns of Peracarida (Crustacea, Malacostraca) in the River Danube. Fund Appl Limnol 187: 113-126.

Borza P, Huber T, Leitner P, Remund N, Graf W. 2017. Success factors and future prospects of Ponto-Caspian peracarid (Crustacea: Malacostraca) invasions: is "the worst over"? Biol Invasions 19: $1517-1532$

Borza P, Kovács K, György A, Török JK, Egri Á. 2019. The PontoCaspian mysid Paramysis lacustris (Czerniavsky, 1882) has colonized the Middle Danube. Knowl Manag Aquat Ecosyst 420: 1.

Casquet J, Thebaud C, Gillespie RG. 2012. Chelex without boiling, a rapid and easy technique to obtain stable amplifiable DNA from small amounts of ethanol-stored spiders. Mol Ecol Res 12: 136-141.

Cristescu MEA., Hebert PDN. 2005. The "Crustacean Seas" an evolutionary perspective on the Ponto Caspian peracarids. Can J Fish Aquat Sci 62: 505-517.

Cristescu MEA, Hebert PDN, Onciu TM. 2003. Phylogeographyof Ponto-Caspian crustaceans: a benthic-planktonic comparison. Mol Ecol 12: 985-996.

Cristescu MEA, Witt JDS, Grigorovich IA, Hebert PDN, MacIsaac HJ. 2004. Dispersal of the Ponto-Caspian amphipod Echinogammarus ischnus: Invasion waves from the Pleistocene to the present. Heredity 92: 197-203.

Dedju II. 1980. Amfipody presnykh i solonovatykh vod yugozapada SSSR, Izdatelstvo "Shtiinca", Kishinev, 223 p.

Dobrzycka-Krahel A, Surowiec J. 2011. Osmoregulation in Pontogammarus robustoides (G.O. Sars, 1894) (Amphipoda) and its distribution in the brackish waters of Northern Poland. Crustaceana 84: 1755-1767

Eggers TO, Martens A. 2001. A key to the freshwater Amphipoda (Crustacea) of Germany. Lauterbornia 42: 1-70.

Grabowski M, Bącela K, Konopacka A. 2007. How to be an invasive gammarid (Amphipoda: Gammaroidea) - comparison of life history traits. Hydrobiologia 590: 75-84. 
Hou ZG, Fu JH, Li SQ. 2007. A molecular phylogeny of the genus Gammarus (Crustacea: Amphipoda) based on mitochondrial and nuclear gene sequences. Mol Phylogenet Evol 45: 596-611.

Hou Z, Sket B, Li S. 2013. Phylogenetic analyses of Gammaridae crustacean reveal different diversification patterns among sister lineages in the Tethyan region. Cladistics 30: 352-364.

Jazdzewska A, Jazdzewski K. 2008. Pontogammarus robustoides (G. O. Sars, 1894) (Crustacea, Amphipoda), a new Ponto-Caspian invader in great Masurian lakes (NE Poland). Fragm Faun 51: 1-7.

Jazdzewski K. 1980. Range extensions of some gammaridean species in European inland waters caused by human activity. Crustaceana Suppl 6: 84-107.

Jermacz Ł, Dzierżyńska A, Poznańska M, Kobak J. 2015. Experimental evaluation of preferences of an invasive PontoCaspian gammarid Pontogammarus robustoides (Amphipoda, Gammaroidea) for mineral and plant substrata. Hydrobiologia 746: 209-221.

Kearse M, Moir R, Wilson A, et al. 2012. Geneious Basic: an integrated and extendable desktop software platform for the organization and analysis of sequence data. Bioinformatics 28: $1647-1649$.

Kiss T, Oroszi VG, Sipos G, Fiala K, Benyhe B. 2011. Accelerated overbank accumulation after nineteenth century river regulation works: A case study on the Maros River, Hungary. Geomorphology 135: 191-202.

Kobak J, Jermacz Ł, Rutkowska D, Pawłowska K, Witkowska L, Poznańska M. 2017. Impact of predators and competitors on the depth selection by two invasive gammarids. J Zool 301: 174-183.

Kurashov EA, Barbashova MA. 2008. First record of the invasive Ponto-Caspian amphipod Pontogammarus robustoides G.O. Sars, 1894 from Lake Ladoga, Russia. Aquat Invasions 3: 253-256.

Librado P, Rozas J. 2009. DnaSP v5: a software for comprehensive analysis of DNA polymorphism data. Bioinformatics 25: $1451-1452$.

Messner U, Zettler ML. 2016. Die aktuelle Verbreitung von Amphipoda (Crustacea) im Verlauf der Oberen Havel. Lauterbornia 81: 57-69.

Moedt S, van Haaren T. 2018. Pontogammarus robustoides (Sars, 1894), a new non-indigenous amphipod in the Netherlands (Crustacea: Amphipoda). Lauterbornia 85: 123-126.

Mordukhai-Boltovskoi FD. 1964. Caspian fauna beyond the Caspian Sea. Int Revue ges Hydrobiol 49: 139-176.

Mordukhai-Boltovskoi FD, Greeze II, Vasilenko SV. 1969. Otryad amphipody ili raznonogie - Amphipoda Latreille, 1816-17. In Kiseleva MI, Mordukhai-Boltovskoi FD, Murina VV, eds. Opredelitel fauny Chernogo i Azovskogo morei. Kiev, USSR: Izdatelstvo Naukova Dumka, pp. 440-524.

Nei M, Kumar S. 2000. Molecular Evolution and Phylogenetics. New York, NY: Oxford University Press, 348 p.
Özbek M. 2011. Distribution of the Ponto-Caspian amphipods in Turkish fresh waters: an overview. Med Mar Sci 12: 447-453.

Panov VE, Berezina NA. 2002. Invasion history, biology and impacts of the Baikalian amphipod Gmelinoides fasciatus. In Leppäkoski E, Gollasch S, Olenin S, eds. Invasive Aquatic Species of Europe Distribution, Impacts and Management. Dordrecht: Kluwer Academic Publishers, pp. 96-103.

Pinder LCV. 1995. The habitats of chironomid larvae. In Armitage PD, Cranston PS, Pinder LCV, eds. The Chironomidae. Biology and ecology of non-biting midges. London: Chapman \& Hall, pp. 107-135.

Popescu-Marinescu V, Nastasesu M, Marinescu C, Cutas F, Neagu E. 2001. Amphipoda (Gammaridae and Corophiidae) from Romanian stretch of Danube before and after the construction of the Iron Gates I damlake. Trav Mus Natl Hist Nat Grigore Antipa 43: 347-366.

Poznańska M, Kakareko T, Krzyżyński M, Kobak J. 2013. Effect of substratum drying on the survival and migrations of Ponto-Caspian and native gammarids (Crustacea: Amphipoda). Hydrobiologia 700: 47-59.

Rachalewski M, Banha F, Grabowski M, Anastáció PM. 2013. Ectozoochory as a possible vector enhancing the spread of an alien amphipod Crangonyx pseudogracilis. Hydrobiologia 717: 109-117.

Ratnasingham S, Hebert PD. 2007. BOLD: The Barcode of Life Data System (http://www.barcodinglife.org). Mol Ecol Res 7: 355-364.

Ratnasingham S, Hebert PD. 2013 A DNA-based registry for all animal species: the Barcode Index Number (BIN) system. PloS ONE 8: e66213.

Rewicz T, Konopacka A, Bącela-Spychalska K, Özbek M, Grabowski M. 2016. First records of two formerly overlooked Ponto-Caspian amphipods from Turkey: Echinogammarus trichiatus (Martynov, 1932) and Dikerogammarus villosus (Sovinsky, 1894). Turk J Zool 40: 328-335.

Saitou N, Nei M. 1987. The neighbor-joining method: A new method for reconstructing phylogenetic trees. Mol Biol Evol 4: 406-425.

Šidagyte E, Arbačiauskas K. 2016. Resistance to low oxygen in the Ponto-Caspian amphipod Pontogammarus robustoides varies among lentic habitats of its northern invaded range. Limnologica 61: 7-13.

Tamura K, Stecher G, Peterson D, Filipski A, Kumar S. 2013. MEGA6: Molecular Evolutionary Genetics Analysis version 6.0. Mol Biol Evol 30: 2725-2729.

Zettler M. 1998. Zur Verbreitung der Malacostraca (Crustacea) in den Binnen- und Küstengewassern von Mecklenburg-Vorpommern. Lauterbornia 32: 49-65.

Żytkowicz J, Kobak J, Kakareko T, Kentzer A. 2008. Species composition and distribution of invasive Ponto-Caspian amphipods in the off-channel microhabitats of a temperate, lowland dam reservoir. Int Rev Hydrobiol 93: 62-72.

Cite this article as: Csabai Z, Borza P, Rewicz T, Pernecker B, Berta BJ, Móra A. 2020. Mass appearance of the Ponto-Caspian invader Pontogammarus robustoides in the River Tisza catchment: bypass in the southern invasion corridor? Knowl. Manag. Aquat. Ecosyst., 421,9 . 